\title{
Effect of Nitrogen Rates on Leaf Quality of Two Cassava (Manihot Esculenta (rantz) Varieties as a Feed for Eri-Silkworm (Samia Cynthia Ricini Boisduval) Cocoon Production at Jimma, Southwest
}

\section{Ethiopia}

Keywords: Nitrogen rates; Cassava leaf; Samia cynthia ricini; Biochemical composition; Cocoon traits

\section{Abstract}

Limited research efforts have been made on cassava leaf usage for rearing eri-silkworm in relation to nitrogen fertilizer management Hence, field and laboratory experiments were conducted at Jimma University (Ela-dale Site) during 2016 with the objective of determining the effect of nitrogen on leaf quality and identifying appropriate cassava variety for better leaf quality as a feed for Eri-silkworm performance. A $2 \times 5$ factorial experiment arranged in Randomized Complete Block Design (RCBD) with three replications was used. The treatments consisted of two cassava varieties (Kello and Qulle) and five levels of $\mathrm{N}(0,40,80,120$ and $160 \mathrm{~kg} \mathrm{~N}$ ha-1) as Urea. For the laboratory experiment, to rear eri-silkworm, cassava leaves harvested from the field experiment (10 plots) were arranged in Completely Randomized Design (CRD) with three replications and their effect on Eri-silkworm performance assessed in terms of larval, cocoon, and post cocoon traits. Data were collected on growth attributes, leaf proximate analysis of cassava, eri-silkworms larval, and cocoon and post cocoon traits. Variety and nitrogen had variable in both laboratory and fields experiment including biochemical composition of leaves. Variety Kello was found to be superior compared to Qulle by revealing a silkworm rearing performance indicators of hatchability $(90.23 \%)$, fecundity (366.2 eggs/female), shorter larval duration (18.46 days), better larval weight $(6.27 \mathrm{gm})$, survival rate $(92.66 \%)$, cocoon weight $(3.44 \mathrm{gm})$ single shell weight $(0.47 \mathrm{gm})$, pupal weight $(2.96 \mathrm{gm})$ and effective rate of rearing (89\%). Application of $160 \mathrm{~kg} \mathrm{~N}$ ha-1 gave highest hatchability (93.85\%), fecundity (384.83 eggs per female), larval weight ( $6.5 \mathrm{gm})$, shell weight $(0.51 \mathrm{gm})$, cocoon weight $(3.66 \mathrm{gm})$, pupal weight $(3.15$ $\mathrm{gm}$ ) and shortest larval duration (17.333 days). In terms of biochemical composition, kello leaves had higher moisture content $(0.438 \%)$, ash (18.541\%) and crude fat (16.69\%). Higher crude fiber (16.248\%) and total carbohydrate $(27.234 \%)$ were obtained from Qulle variety. 160 $\mathrm{kg} \mathrm{N}$ ha-1 gave the highest moisture $(0.467 \%)$ and the lowest crude fiber (14.123\%). The highest leaf nitrogen content $(4.802 \%)$ and crude protein $(30.012 \%)$ was gained from the combination of kello and 160 $\mathrm{kg} \mathrm{N}$ ha-1. In conclusion, variety Kello and $160 \mathrm{~kg} \mathrm{~N}$ ha-1 can be used for higher leaf yield, leaf quality and cocoon yield.

\section{Introduction}

In Ethiopia, agricultural production is of a subsistence nature. The agricultural production system is mainly rain fed and traditional, which is characterized by low input of improved seeds, fertilizer, pesticides and other technologies [1]. Poverty and increasing population pressure led to decline in land holding per household that eventually resulted in low level of production to meet even the consumption requirement of the households [2]. Poverty reduction and Increases in the unemployment rate due to increases in the population, therefore, requires income generation activities like mass rearing of silk producing organisms to obtain silk [3].

More than $85 \%$ of the Ethiopian population, which resides in the rural area, is engaged in agricultural production as a major means of livelihood [4]. The Ethiopian government's development policy emphasizes agricultural sector development led industrialization. In 1996, the government initiated a food security strategy built around, increasing agricultural production at the household level, ensuring access to food for food deficit households, and strengthening institutional emergency response capabilities to achieve food security $[5,6]$.

Sericulture provides gainful employment, economic development and improvement in the quality of life to the people in rural area and therefore it plays an important role to meet this policy. It provides employment at various levels [7]. In his review of sericulture Industry in India classified the employment generation pattern of the industry into two major types: (i) Direct Employment - (a) Mulberry Cultivation; (b) Leaf Harvesting; (c) Silk Worm Rearing; (ii) Indirect Employment - (a) Reeling; (b) Twisting; (c) Weaving; (d) Printing \& Dyeing; (e) Finishing; (f) Silk Waste Processing [8];

Sericulture is an agro-based industry. Sericulture provides economic development and improvement in the quality of life to the people in rural area and therefore it plays an important role in anti-poverty programme and prevents migration of rural people to urban area in search of employment. It can make employment up to 11 persons for every kilogram of raw silk produced; out of which more than 6 persons are women [9]. Estimated that one hectare of mulberry creates employment of 13-16 persons per year and their location specific analysis indicated that for a production of one kilogram of raw silk, 11 man days are required which can, in turn, employ 30 man days for production of silk fabric. Showed that 96.36 
Citation: Derara Y, Sori W, Nebiyu A, Mulat F. Effect of Nitrogen Rates on Leaf Quality of Two Cassava (Manihot Esculenta Crantz) Varieties as a Feed for Eri-Silkworm (Samia Cynthia Ricini Boisduval) Cocoon Production at Jimma, Southwest Ethiopia. J Plant Biol Soil Health. $2020 ; 6(2)$ : 11.

man days of employment are generated from the establishment of one acre of mulberry garden for rearing $300 \mathrm{dfls}$ (disease free layings) of silkworms in two months [10].

Historical evidence show that silk was discovered in China and from there it spread to other parts of the world. Silk is produced by the larvae from a variety of insects and spiders of the phylum Arthropoeda. It is a natural protein fiber and is very soft, lustrous, smooth, strong and durable than any natural or artificial fiber [11] Silkworm is a kind of insect which can produce silk solution. Insects mainly belong to two families, viz., Saturnidae and Bombycidae, which spins silk fibre [12]. Among saturniidae family S.c ricini is the one commercially exploited silkworm species and can be reared in doors throughout the year to produce silk $[13,14]$. Bombyx mori belongs to Bombycidae produces a delicate twin thread of silk fibroin, which is coated by a protective cover of sericin. Silk protein is a kind of protein like collagen, elastin, keratin, fibroin, sporgin etc., is an essential constituent of cocoon filament [15]. Reported that the silk fiber is almost a pure protein fiber composed of two types of proteins viz., sericin and fibroin [16].

Cassava, the most preferred food plant after castor has also been proved to be suitable for commercial rearing of silkworm. Cassava growers can divert a portion of foliage (25-40\%) to raise eri silkworm and get extra income without affecting the tuber yield and starch content [17-19]. Also stated that cassava cultivation for eri silkworm rearing provides gainful employment to the women [20].

Eri silkworm is a domesticated multivoltine non-mulberry silkworm. It is a sericigenous insect exploited for its valuable eri silk. It is a multivoltine insect completing at least six to seven generations in a year and it can be reared throughout the year depending on the availability feed $[14,21]$. The agro-ecology and feed availability are the major requirements which have significant effect on rearing of larvae of this insect and finally cocoon crop yield and quality. It is a domesticated silkworm that feeds primarily on leaves of the castor plant. Eri-silkworm shows different rearing behavior when fed different food plants [22]. Eri-silkworm rearing also relies on management practices i.e., rearing temperature, humidity and nutrition. The healthier rearing conditions, environment and nutrition during larval period may lead to higher fecundity by silkworm moths $[23,24]$.

The quality of feed plays a very important role for growth and development of the eri-silkworm and ultimately on the economic traits of cocoons. Leaf is a key factor besides environment and technology adoption for better growth and development of the silkworm larvae and cocoon production [25-27]. Reported that, among the various factors influencing silkworm growth and cocoon production, leaf quality plays a major role [28]. Eri- silkworm fed with more moisture, protein, sugar and carbohydrates and less minerals and crude fibre content is the best from the silkworm nutrition point of view [29].

Nitrogen application influences the quality of feed (leaf) especially its protein content [30,31]. As nitrogen is an important limiting factor for phytophagous insects, reduction of nitrogen contents has forceful effects on insect performances. The weights of larvae and cocoons of eri-silkworm are significantly influenced by nitrogen content of foliage [32]. Deficiencies in Nitrogen can also affect cassava yield in many ways. This might occur through reduction in leaf area, moderate reduction in photosynthetic rates of leaves, modification of branching habit and changes in the distribution patterns of dry matter to different plant parts [33].

Therefore, nitrogen application is very important for eri silkworm performance and cocoon production. In line with this, the present study was carried out with the general objective of evaluating performance of eri-silkworm reared on leaf of two cassava varieties cultivated under different rates of nitrogen application.

\section{Materials and Methods}

\section{Description of the study area}

The experiment was conducted at the experimental field in Jimma University College of Agriculture and Veterinary Medicine, Eladale Site, during 2015/2016 rainy season. It is about $365 \mathrm{~km}$ far from Addis Abeba on the road to Bedele. The research site is geographically located at $7 \mathrm{o} 42^{\prime} \mathrm{N}$ latitude and $36 \mathrm{o} 50^{\prime} \mathrm{E}$ longitude with an altitude of $1710 \mathrm{~m}$ above sea level. The dominant soils of the area are Nitisol and Cambisol. The area receives an average annual rainfall of $1530 \mathrm{~mm}$. The area has an average maximum and minimum temperature of 26.2 ${ }^{\circ} \mathrm{C}$ and $11.3{ }^{\circ} \mathrm{C}$, respectively and average maximum and minimum relative humidity of $91.40 \%$ and $37.92 \%$, respectively [34].

Agriculture is the main occupation of the area and raising silkworm for eri cocoon production is not widely practiced but recently people in the study area are familiarized with silkworm production as a source of income.

\section{Experimental materials and treatments}

Two cassava varieties, namely Kello and Qulle, which were developed and released in 2005 by Hawassa Agricultural Research Centre, were used for this experiment. They were chosen for the study because of the fact that they have a wide range of adaptation and are high yielders and popular among farmers in the south and southwestern part of Ethiopia.

Eggs (seeds) of white plain 2.4 breed of eri-silkworm were used to study the effect of varieties and rates of nitrogen on eri-silkworms larval growth, cocoon and post cocoon characters. This type of erisilkworm is hardy, disease resistant and can easily be reared [3].

The treatment consisted of factorial combinations of two cassava varieties (Kello and Qulle) and five different nitrogen rates $\left(0,40,80,120\right.$ and $\left.160 \mathrm{~kg} \mathrm{ha}^{-1}\right)$ in the form of urea $(46 \% \mathrm{~N})$. Each level of nitrogen was combined with two levels of varieties. The national blanket fertilizer recommendation for cassava $\left(80 \mathrm{~kg} \mathrm{~N} \mathrm{ha}^{-1}\right)$ was used as a bench mark in the experiment.

\section{Experimental designs}

A. Field experiment: The field experiment to study the effect of nitrogen rates on leaf quality of two cassava varieties consisted of factorial combinations of two cassava varieties (Kello and Qulle) and five different nitrogen rates $\left(0,40,80,120\right.$ and $\left.160 \mathrm{~kg} \mathrm{ha}^{-1}\right)$ laid out in Randomized Complete Block Design forming 10 treatment combinations each replicated thrice. Gross plot size was $5 \mathrm{~m}$ x $4 \mathrm{~m}$ (20 $\mathrm{m}^{2}$ ) and the stem cuttings were planted at the spacing of $1 \mathrm{~m}$ between rows and $1 \mathrm{~m}$ between plants. There were five rows per a single plot 
Citation: Derara Y, Sori W, Nebiyu A, Mulat F. Effect of Nitrogen Rates on Leaf Quality of Two Cassava (Manihot Esculenta Crantz) Varieties as a Feed for Eri-Silkworm (Samia Cynthia Ricini Boisduval) Cocoon Production at Jimma, Southwest Ethiopia. J Plant Biol Soil Health. $2020 ; 6(2)$ : 11.

and four stem cuttings were planted per row. The total number of stem cuttings per a single plot was therefore 20 . The distance between plot and block was 1 meter and 1.5 meters, respectively leaving the outermost rows on both sides of each plot to avoid border effects. The entire experimental area was $882 \mathrm{~m}^{2}$.

B. Laboratory eri-silkworm rearing experiment: A laboratory experiment consisting of leaves of two cassava varieties (Kello and Qulle) grown under five rates of nitrogen $\left(0,40,80,120,160 \mathrm{~kg} \mathrm{~N} \mathrm{ha}^{-1}\right)$ were arranged in Completely Randomized Design (CRD) to form 10 treatment combinations each replicated thrice. Therefore, there were 30 plastic trays in the rearing room which represented the plots on the field. A single plastic tray contained 20 worms. Total worms on trays were 600 .

\section{Experimental procedures}

A. Field experiment: The experimental field was prepared following the conventional tillage practice before planting the stem cuttings. The stem cuttings of about $30 \mathrm{~cm}$ long were planted on ridges at 450 according to the recommended space of $1 \mathrm{~m}$ by $1 \mathrm{~m}$ during the onset of the main rainy season. Urea $(46 \% \mathrm{~N})$ fertilizer was used as a source of nitrogen. The nitrogen fertilizer was divided in two equal splits and the first half was applied during first month and the remaining half was side dressed three month after planting [35].

B. Laboratory eri-silkworm rearing experiment: Eggs of erisilkworm were procured from Jimma Agricultural Research Center. Rearing room and appliances was cleaned before starting rearing eri silkworm with $2 \%$ formalin solutionto protect pathogens which infect eri silkworm [36,37]. The room was kept open for a minimum of 12 hours to remove the traces of formalin vapor left over in the room before the starting of the rearing experiments. The eggs procured were subjected to surface sterilization with $2 \%$ formalin solution and washed with clean water and dried under shade to ensure proper hatching [38]. After drying, the eggs were incubated at normal room temperature till hatching. The newly hatched larvae were selected and transferred with the help of forceps to rearing tray.

Rearing was undertaken as per the standard rearing technique under laboratory conditions from first to fifth instar on (Jan-March) and (April-June) [39,40]. Fresh and healthy leaves of Kello and Qulle varieties of cassava were used in the present study. The leaves were harvested daily from the cassava garden during the early hours of the day and stored cool to maintain its freshness. The first and second instar larvae were fed with tender leaves; medium aged leaves were fed to the third instar larvae and matured leaves to the fourth and fifth instar larvae. The larvae were continuously fed at a frequency of four times per day at intervals of six hours except during molting periods [42]. The quantity of food was increased with the advancement of larval age to fulfill their requirement. Bed cleaning was done to ensure the cleanliness in the immediate locality of silkworms in order to protect from disease infection and to ensure them good feeding appetite [43]. Adequate ventilation was ensured to the larvae by placing the trays one above the others crosswise. The matured larvae were relocated to suitable mountages separately for spinning of cocoons [44]. Cocoon harvesting was done after the sixth day of spinning [45]. This procedure was conducted for two life cycles of silkworm due to the fact that the previous feed of the eggs of eri-silkworm brought from Jimma agricultural research center was castor. Data on grainage parameters (hatchability and fecundity), larval parameters (larval duration, larval weight, survival rate and effective rate of rearing) and cocoon parameters (shell weight, cocoon weight, pupal weight and silk ratio) were assessed, recorded and statistical analysis was performed using standard tools.

\section{Data collected}

Leaf proximate analysis: The leaf samples at three different heights of the plant viz., top, middle and bottom, were collected in paper bags at 180 days after stem planting and composite leaf samples were made. Leaves were shade dried for three days and then dried in hot air oven at $70{ }^{\circ} \mathrm{C}$ until constant weight was gained. The dried leaf samples were ground into fine powder and well-maintained in butter paper bags for chemical analysis. Each sample had three replications. As adopted by [46], crude protein was estimated by multiplying the estimated value of the total nitrogen by 6.25 , while the total nitrogen content of the leaf was determined by Kjeldahl method. Techniques and procedures of A.O.A.C. (2000) were used to determine crude fiber and crude fat contents [47]. The method of was used to estimate total minerals (ash) composition and total carbohydrates [48]. Accordingly, total carbohydrate was determined by the method of subtracting the percentage values of protein, fat, ash and fiber from 100.

Eri-silkworm characteristics: Grainage Parameters: Hatchability (\%): After complete hatching (third day from the beginning of hatching) the laying was counted to collect the data in respect to the total number of eggs laid per female moth, number of unfertilized eggs and number of hatched eggs per layings. The average hatching of five layings was taken as representative hatchability percentage per layings in this case [45].

Eggs hatchability $(\%)=\frac{\text { Number of normal eggs }- \text { number of non hatched eggs }}{\text { Number of normal eggs }} \times 100$

B. Fecundity (eggs/ female moth): Pairs of freshly emerged moth were placed on mountage and kept hanging on a wire. There were three replications of five pairs of moths in each replication for each treatment tested. The moths were decoupled after three hours and the female moths were allowed to lay eggs on the mountage. After three days, the eggs laid were separated from the mountage and counted replication wise to find out the fecundity and was recorded as numbers of egg per female.

\section{Larval parameters}

A. Larval duration (days): The larval duration is the period between hatching of eggs and maturity of the larvae and was recorded in each treatment replication wise in days.

B. Larval weight $(\mathbf{g m})$ : The weight of $5^{\text {th }}$ in star larvae was taken when the larvae stopped eating; body became pale and excreted the last excreta. Five larvae were randomly picked from each treatment and weighed treatment and replication wise and their average was calculated.

C. Survival rate of larvae (\%): This was measured by dividing the number of survived larvae by number of larvae brushed and expressed in terms of percent [45]. 
Citation: Derara Y, Sori W, Nebiyu A, Mulat F. Effect of Nitrogen Rates on Leaf Quality of Two Cassava (Manihot Esculenta Crantz) Varieties as a Feed for Eri-Silkworm (Samia Cynthia Ricini Boisduval) Cocoon Production at Jimma, Southwest Ethiopia. J Plant Biol Soil Health. $2020 ; 6(2)$ : 11.

ISSN: $2331-8996$

Table 1: Effect of varieties and rates of nitrogen on proximate leaf composition of two cassava varieties.

\begin{tabular}{|c|c|c|c|c|c|}
\hline \multicolumn{6}{|c|}{ Cassava leaf mineral composition } \\
\hline Factors & Moisture (\%) & $\begin{array}{c}\text { Crude } \\
\text { fiber (\%) }\end{array}$ & Ash (\%) & Crude fat (\%) & Total carbohydrate (\%) \\
\hline \multicolumn{6}{|l|}{ Varieties } \\
\hline Kello & $43.8^{a}$ & $15.06^{b}$ & $18.54^{\mathrm{a}}$ & $16.69^{a}$ & $22.79^{b}$ \\
\hline Qulle & $41.8^{b}$ & $16.25^{\mathrm{a}}$ & $17.68^{\mathrm{b}}$ & $15.99^{b}$ & $27.23^{\mathrm{a}}$ \\
\hline LSD (5\%) & 0.01 & 0.48 & 0.16 & 0.22 & 0.66 \\
\hline \multicolumn{6}{|c|}{ Nitrogen $\mathrm{Kg} / \mathrm{ha}^{-1}$} \\
\hline 0 & $38.8^{e}$ & $18.83^{\mathrm{a}}$ & $15.44^{d}$ & $13.44^{\mathrm{e}}$ & $31.03^{\mathrm{a}}$ \\
\hline 40 & $40.8^{d}$ & $16.11^{\mathrm{b}}$ & $18.39^{\circ}$ & $15.83^{d}$ & $26.42^{\mathrm{b}}$ \\
\hline 80 & $43^{c}$ & $15.07^{c}$ & $19.17^{\mathrm{a}}$ & $16.17^{c}$ & $24.92^{\mathrm{c}}$ \\
\hline 120 & $44.6^{\mathrm{b}}$ & $14.14^{\mathrm{d}}$ & $18.82^{\mathrm{b}}$ & $18.49^{a}$ & $22.46^{\mathrm{d}}$ \\
\hline 160 & $46.7^{a}$ & $14.13^{d}$ & $18.74^{\mathrm{b}}$ & $17.76^{b}$ & $20.25^{e}$ \\
\hline LSD & 0.014 & 0.771 & 0.25 & 0.35 & 0.97 \\
\hline CV $(\%)$ & 2.747 & 4.089 & 1.17 & 1.76 & 3.21 \\
\hline
\end{tabular}

Where: LSD: Least Significant Difference; CV: Coefficient of Variation. Means followed by the same letters within a column are not significantly different at $5 \% \mathrm{P}$ level.

Table 2: Interaction effect of varieties and nitrogen rates on nitrogen and crude protein content of two varieties of cassava leaf.

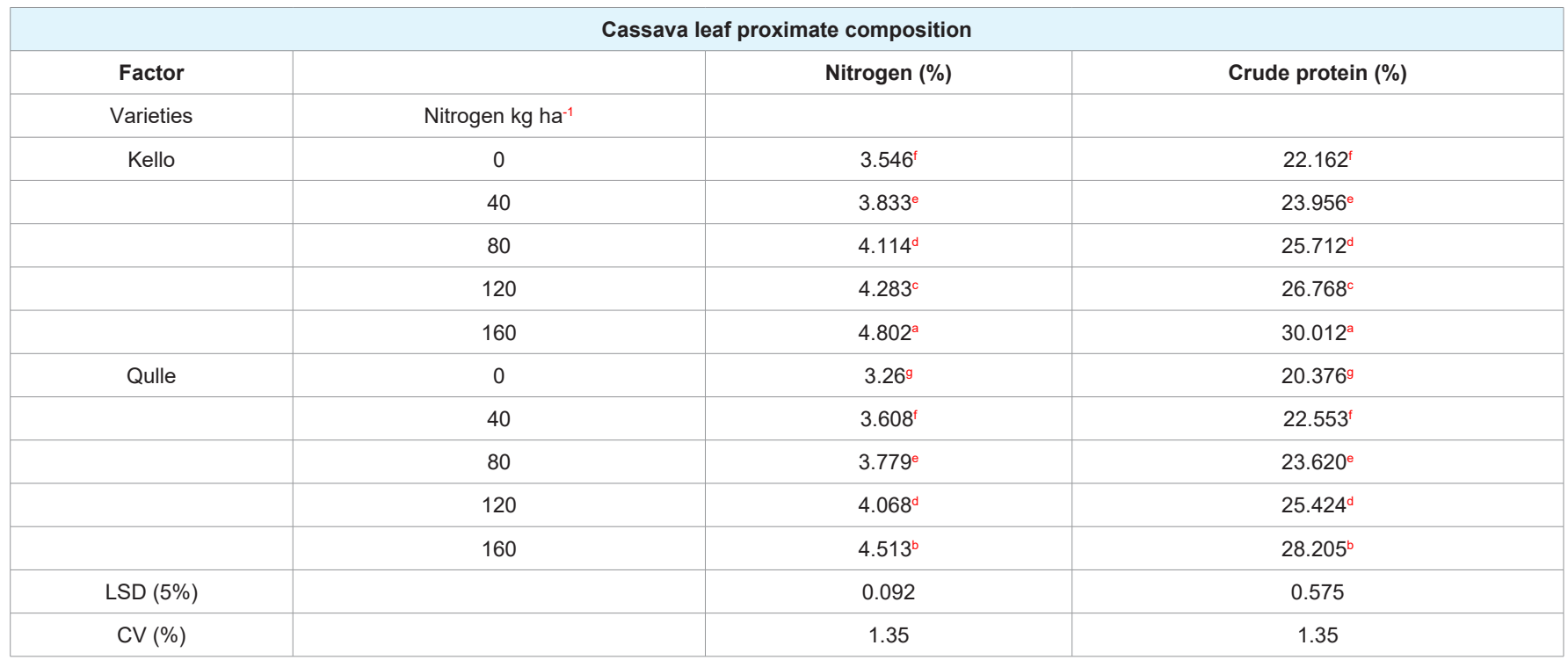

Where: LSD: Least Significant Difference; CV: Coefficient of Variation. Means followed by the same letters within a column are not significantly different at $5 \% \mathrm{P}$ level.

$$
\text { Survival rate }(\%)=\frac{\text { Number of larvae survived }}{\text { Number of larvae brushed }} \times 100
$$

D. Effective rate of rearing (\%): This is the number of larvae spinning cocoons out of the number of larvae brushed and is expressed in percentage [45].

$$
\text { ERR }(\%)=\frac{\text { Number of larvae spinning cocoon }}{\text { Number of larvae brushed }} \times 100
$$

\section{Cocoon parameters}

A. Single cocoon weight (gm): On the sixth days of spinning, five cocoons were randomly harvested from each treatment and individual cocoon weight was weighted and their average was recorded [45].

B. Shell weight (gm): Randomly selected five cocoons were cut open, their pupae and larval excuvium were removed and average shell weight was recorded separately.

C. Pupal weight (gm): Similarly, after the cocoons were cut open, single pupa weight was recorded using sensitive balance. It can also be obtained by subtracting the shell and exuviae weight from the cocoon weight.

D. Shell ratio (\%): The amount of silk present in a cocoon shell was expressed in percentage. It is weight of cocoon shell out of weight of the cocoon with pupa [39]. 
Citation: Derara Y, Sori W, Nebiyu A, Mulat F. Effect of Nitrogen Rates on Leaf Quality of Two Cassava (Manihot Esculenta Crantz) Varieties as a Feed for Eri-Silkworm (Samia Cynthia Ricini Boisduval) Cocoon Production at Jimma, Southwest Ethiopia. J Plant Biol Soil Health. $2020 ; 6(2)$ : 11.

ISSN: $2331-8996$

Table 3: Effect of varieties and nitrogen rates on grainage parameters of eri-silkworm.

\begin{tabular}{|c|c|c|c|c|}
\hline \multicolumn{3}{|c|}{ First cycle } & \multicolumn{2}{|c|}{ Second cycle } \\
\hline Factors & Hatchability (\%) & Fecundity (eggs no / female moth) & Hatchability (\%) & Fecundity (eggs no/ female moth) \\
\hline \multicolumn{5}{|l|}{ Varieties } \\
\hline Kello & $90.23^{a}$ & $366.2^{\mathrm{a}}$ & $88.35^{a}$ & $356.46^{\mathrm{a}}$ \\
\hline Qulle & $88.58^{b}$ & $355^{\mathrm{b}}$ & $86.72^{\mathrm{b}}$ & $346.8^{b}$ \\
\hline LSD & 1.11 & 5.819 & 1.08 & 6.055 \\
\hline \multicolumn{5}{|l|}{$\mathrm{N} \mathrm{kg} \mathrm{ha}^{-1}$} \\
\hline 0 & $83.75^{d}$ & $336.83^{d}$ & $82.28^{d}$ & $330.50^{d}$ \\
\hline 40 & $87.18^{\mathrm{c}}$ & $352.66^{c}$ & $85.12^{\mathrm{c}}$ & $344.83^{c}$ \\
\hline 80 & $90.16^{b}$ & $358.83^{c}$ & $88.50^{\mathrm{b}}$ & $349.67^{\mathrm{bc}}$ \\
\hline 120 & $92.10^{\mathrm{a}}$ & $369.83^{b}$ & $89.97^{b}$ & $358.67^{b}$ \\
\hline 160 & $93.85^{a}$ & $384.83^{a}$ & $91.82^{\mathrm{a}}$ & $374.5^{\mathrm{a}}$ \\
\hline LSD (\%) & 1.76 & 9.2 & 1.72 & 9.57 \\
\hline CV (\%) & 1.635 & 2.11 & 1.632 & 2.26 \\
\hline
\end{tabular}

Where: LSD: Least Significant Difference; CV: Coefficient of Variation. Means followed by the same letters within a column are not significantly different at $5 \% \mathrm{P}$ level.

Table 4: Effect of varieties and nitrogen rates on larval parameters of eri-silkworm.

\begin{tabular}{|c|c|c|c|c|c|c|c|c|}
\hline \multicolumn{5}{|l|}{ First cycle } & \multicolumn{4}{|c|}{ Second cycle } \\
\hline Factors & \multirow{2}{*}{$\begin{array}{l}\text { LW } \\
\text { (gm) }\end{array}$} & LD (days) & SRv (\%) & ERR (\%) & \multirow[t]{2}{*}{ LW } & \multirow[t]{2}{*}{ LD (days) } & \multirow[t]{2}{*}{ SRv (\%) } & \multirow[t]{2}{*}{ ERR (\%) } \\
\hline (gm) & & & & & & & & \\
\hline \multicolumn{9}{|l|}{ Varieties } \\
\hline kello & $6.27^{a}$ & $18.46^{b}$ & $92.66^{a}$ & $89^{a}$ & $5.92^{\mathrm{a}}$ & $19.67^{b}$ & $91^{\mathrm{a}}$ & $85^{\mathrm{a}}$ \\
\hline Qulle & $5.82^{\mathrm{b}}$ & $19.26^{\mathrm{a}}$ & $89.33^{b}$ & $84.33^{b}$ & $5.62^{\mathrm{b}}$ & $20.47^{a}$ & $86^{b}$ & $79^{b}$ \\
\hline LSD (5\%) & 0.28 & 0.62 & 2.78 & 4.17 & 0.2 & 0.62 & 2.86 & 2.51 \\
\hline \multicolumn{9}{|l|}{$\mathrm{N} \mathrm{kg} \mathrm{ha-1}^{-1}$} \\
\hline 0 & $5.71^{\mathrm{c}}$ & $20.16^{a}$ & $90^{\mathrm{a}}$ & $86.67^{a}$ & $5.5^{c}$ & $21.16^{a}$ & $87.5^{a}$ & $80.83^{a}$ \\
\hline 40 & $5.83^{\mathrm{bc}}$ & $19.66^{a}$ & $90^{\mathrm{a}}$ & $85^{a}$ & $5.56^{\mathrm{bc}}$ & $20.66^{a}$ & $87.5^{\mathrm{a}}$ & $80.83^{a}$ \\
\hline 80 & $5.93^{b c}$ & $18.66^{b}$ & $90^{\mathrm{a}}$ & $85.83^{a}$ & $5.63^{b c}$ & $20.66^{a}$ & $87.5^{\mathrm{a}}$ & $81.67^{a}$ \\
\hline 120 & $6.26^{a b}$ & $18.5^{b}$ & $90^{\mathrm{a}}$ & $85.83^{a}$ & $5.97^{\mathrm{ab}}$ & $19.5^{b}$ & $88.33^{a}$ & $81.67^{a}$ \\
\hline LSD (5\%) & 0.45 & 0.98 & 5.39 & 6.59 & 0.45 & 0.98 & 5.53 & 4.96 \\
\hline CV (\%) & 6.33 & 4.33 & 4.01 & 6.32 & 6.54 & 4.06 & 4.24 & 4.005 \\
\hline
\end{tabular}

Where: LW: Larval Weight; LD: Larval Duration; SRv: Survival Rate; ERR: Effective Rate of Rearing; LSD: Least Significant Difference and CV: Coefficient of Variation. Means followed by the same letters within a column are not significantly different at $5 \% \mathrm{P}$ level.

\section{Shell ratio $(\%)=\frac{\text { Weight of shell }}{\text { weight of cocoon with pupa }} \times 100$}

\section{Data Analysis}

All data collected on different parameters of proximate compositions of leaf, grain age, larval and cocoon parameters were first checked for normality and did not violate the rule. The data were subjected to analysis of variance (ANOVA) using SAS version 9.2 [49]. Significance differences between treatment means were delineated by LSD (Least Significance Difference) test at $5 \%$ level of significance

\section{Results and Discussion}

Effect of Varieties and Nitrogen Rates and their Interaction on

\section{Leaf Proximate Composition of Cassava Varieties}

A. Leaf moisture (\%): Leaf moisture percentage of the two cassava varieties varied highly significantly with higher content being from Kello (43.8\%) as compared to qulle (41.8\%). Variation in moisture content between varieties could be attributable for their inherent characters. The increase in leaf moisture content might be enhancement in hydrogen ion concentration in plant sap due to accumulation of chlorides and less moisture loss by evapotranspiration in the leaves [50]. These results are in conformity with the observations of [51], Sannappa and who observed variations in moisture content of leaves among castor genotypes [52].

From the result, application of different rates of $\mathrm{N}$ resulted in to highly significantly different $(\mathrm{P}<0.001)$ moisture content of the leaf 
Citation: Derara Y, Sori W, Nebiyu A, Mulat F. Effect of Nitrogen Rates on Leaf Quality of Two Cassava (Manihot Esculenta Crantz) Varieties as a Feed for Eri-Silkworm (Samia Cynthia Ricini Boisduval) Cocoon Production at Jimma, Southwest Ethiopia. J Plant Biol Soil Health. $2020 ; 6(2)$ : 11.

ISSN: 2331-8996

Table 5: Effects of varieties and nitrogen rates on cocoon parameters of eri-silkworm.

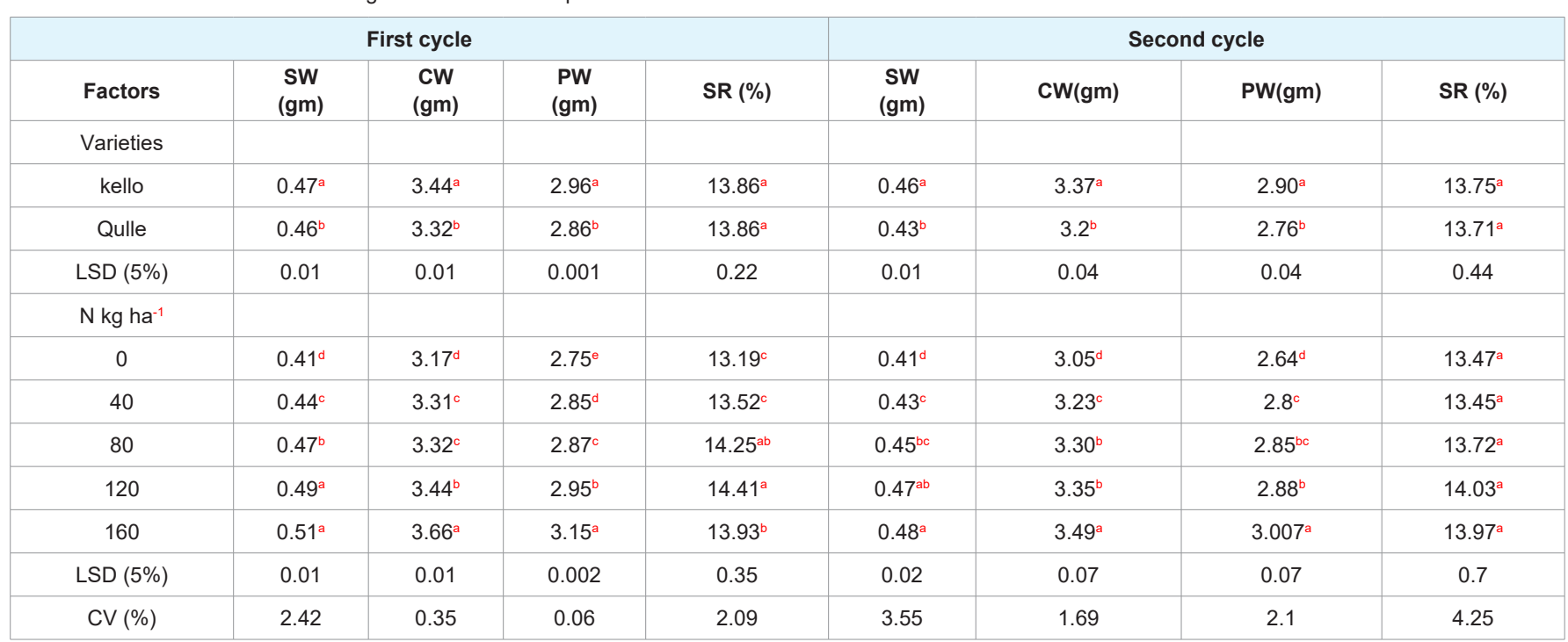

Where: SW: Shell Weight; CW: Cocoon Weight; PW: Pupal Weight; SR: Silk Ratio; LSD: Least Significant Difference and CV: Coefficient of Variation. Means followed by the same letters within a column are not significantly different at $5 \%$ level.

per plant. Moisture content of the leaf increased with the increase in the rates of $\mathrm{N}$. The leaf with highest moisture content was found

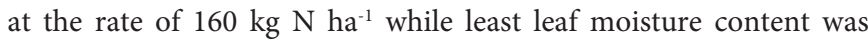
documented with no application of Nitrogen $\left(0 \mathrm{~kg} \mathrm{~N} \mathrm{ha}^{-1}\right)$.

B. Crude fiber (\%): The increase in $\mathrm{N}$ rates caused the decrease of crude fiber from $18.829 \%$ to $14.123 \%$. The highest crude fiber of the leaf was documented at no $\left(0 \mathrm{~kg} / \mathrm{ha}^{-1}\right)$ nitrogen fertilizer rate while the smallest crude fiber was observed at the highest $\left(160 \mathrm{kgN} \mathrm{ha}^{-1}\right)$ nitrogen fertilizer treatment. This shows that increasing $\mathrm{N}$ fertilizer rates decreased crude fiber in the leaf. The decline in crude fiber content with increased $\mathrm{N}$ rates could probably be attributed to the fact that plants tend to use more of their photosynthates on protein rather than carbohydrate synthesis. In case of varieties, there was notable variation between them. Qulle variety revealed higher crude fiber compared to Kello variety. The variation in crude fiber between the varieties may have occurred due to their inherent characters. This finding is supported by the finding of who recorded significant variation in crude fiber among castor genotypes [53]. Similar to this experiment, also observed variation in crude fiber in different castor genotypes [32].

C. Ash (\%): In case of ash content, higher ash content was estimated from the leaves of kello (18.541\%) variety. The main reason for variation in ash content between the varieties could be due to genetic factors (Table 1). Observed significant variation in ash content between eight different castor genotypes [53]. Ash content may also vary due to variation in metal composition in the same plant of different variety [54]. On the other hand, application of different rates of $\mathrm{N}$ highly significantly $(\mathrm{P}<0.001)$ influenced ash content of the leaf per plant. Ash content of the leaf increased gradually with the increase in the rates of $\mathrm{N}$. The leaf with highest ash content (19.17\%) were recorded at the rates of $80 \mathrm{~kg} \mathrm{~N} \mathrm{ha}^{-1}$ while least leaf ash content (15.435\%) was recorded with no $\mathrm{N}$ application $\left(0 \mathrm{~kg} \mathrm{~N} \mathrm{ha}^{-1}\right)$. This low ash content is indicative of the low mineral content of cassava [55].

D. Crude fat (\%): The increase in nitrogen caused an increase in crude fat of leaf. The highest crude fat in the cassava leaf (18.496\%) was registered at the rates of $120 \mathrm{~kg} \mathrm{~N} \mathrm{ha}^{-1}$ application. Crude fat which includes all lipids, chlorophyll, carotenes and all other fat soluble material tends to be enhanced by $\mathrm{N}$ application [56]. The least crude fat content (13.437\%) was recorded with no application of $\mathrm{N}$ $\left(0 \mathrm{~kg} \mathrm{ha}^{-1}\right)$. Crude fat content between two cassava varieties varied highly significantly with higher content being from kello as compared to qulle (Table 1). Variation in crude fat content between varieties could be attributable for their difference in terms of their inherent characters. Consistent with the current findings, findings of observed variation in fat content among castor genotypes [32,57].

E. Total carbohydrate (\%): The total carbohydrate which is analyzed on dry weight basis as a difference of the sum of ash, crude protein, crude fat and crude fiber from 100 also revealed significant variation for different rates of nitrogen and two cassava varieties. Qulle recorded higher carbohydrate content of $27.234 \%$ while Kello registered $22.797 \%$. The difference in total carbohydrate content between the two varieties might be attributed to the variation in genetic factors. The present observation is in agreement with the findings of and who detected variation in the total carbohydrate content among castor genotypes [58-60]. With regard to $\mathrm{N}$, the highest total carbohydrate was gained from application of $0 \mathrm{kgN} \mathrm{ha}^{-1}$. Limited $\mathrm{N}$ supply results in higher level of carbohydrates $[61,56]$. The lowest total carbohydrate was obtained from the highest application of $\mathrm{N}\left(160 \mathrm{~kg} / \mathrm{ha}^{-1}\right)$.

F. Leaf nitrogen (\%): The highest leaf nitrogen was recorded from Kello variety with the application of $160 \mathrm{~kg} \mathrm{~N} \mathrm{ha}^{-1}$ while the lowest nitrogen content was obtained from qulle with no application of $\mathrm{N}$ (Table 2). Leaf nitrogen content ranged between $3.403 \%$ and $4.657 \%$. There was also variation between two cassava varieties. Kello had higher nitrogen content in its leaf than Qulle. This result is in agreement with the findings of [62]; who observed significant difference among castor genotypes in terms of nitrogen content. In the same manner $[32,63]$, also recorded different amount of nitrogen 
Citation: Derara Y, Sori W, Nebiyu A, Mulat F. Effect of Nitrogen Rates on Leaf Quality of Two Cassava (Manihot Esculenta Crantz) Varieties as a Feed for Eri-Silkworm (Samia Cynthia Ricini Boisduval) Cocoon Production at Jimma, Southwest Ethiopia. J Plant Biol Soil Health. $2020 ; 6(2)$ : 11.

from different varieties of castor [64].

G. Crude protein (\%): From the interaction point of view, the highest leaf crude protein $(30.012 \%)$ was recorded from kello variety with the application of $160 \mathrm{~kg} \mathrm{~N} \mathrm{ha}^{-1}$ while the F. Leaf nitrogen (\%): The highest leaf nitrogen was recorded from Kello variety with the application of $160 \mathrm{~kg} \mathrm{~N} \mathrm{ha}^{-1}$ while the lowest nitrogen content was obtained from qulle with no application of $\mathrm{N}$ (Table 2). Leaf nitrogen content ranged between $3.403 \%$ and $4.657 \%$. There was also variation between two cassava varieties. Kello had higher nitrogen content in its leaf than Qulle. This result is in agreement with the findings of who observed significant difference among castor genotypes in terms of nitrogen content $[32,62,63]$. In the same manner, also recorded different amount of nitrogen from different varieties of castor [64].

G. Crude protein (\%): From the interaction point of view, the highest leaf crude protein $(30.012 \%)$ was recorded from kello variety with the application of $160 \mathrm{~kg} \mathrm{~N} \mathrm{ha}^{-1}$ while the lowest crude protein (20.376\%) was obtained from Qulle with no application of nitrogen (Table 2). Higher crude protein content was higher for Kello variety. The variation in the crude protein content between the two varieties may at least partly be attributed to genetic factor. Recorded variation in crude protein content among castor genotypes [51,52,58-60].

Crude protein which is 6.25 times the nitrogen content (Lord, 1968) varied markedly among different rates of nitrogen. The lowest crude protein was gained from no application of nitrogen $\left(0 \mathrm{~kg} \mathrm{~N} \mathrm{ha}^{-1}\right)$ whereas the highest crude protein was obtained from the application of the highest nitrogen $\left(160 \mathrm{~kg} \mathrm{~N} \mathrm{ha}^{-1}\right)$.The possible reason for the increment of protein content as the application of nitrogen increase could be due to the fact that $\mathrm{N}$ is utilized to synthesize amino acids, which in turn form proteins [30,31].

\section{Effect of Varieties and Nitrogen Rates on the Rearing Performance} of Eri-silkworm

Grainage parameters: Significant differences were observed in grainage parameters of eri-silkworms when fed with cassava leaves of two varieties grown on different rates of nitrogen fertilizers (Table 3).

A. Hatchability (\%): During first and second rearing, the highest hatchability was observed from application of $160 \mathrm{~kg} \mathrm{~N} \mathrm{ha}^{-1}$ which was statistically similar with application of $120 \mathrm{~kg} \mathrm{~N} \mathrm{ha}^{-1}$ in the first cycle of rearing while the lowest was recorded from no application of nitrogen $\left(0 \mathrm{kgN} \mathrm{ha}^{-1}\right)$. The probable reason for the increment of hatchability could be due to the increase of leaf nitrogen. The reduction of hatchability during second cycle might be due to the reduction of nutrients in the leaf, in most case, was matured/aged.

In case of varietal impact on eggs hatchability, the higher hatchability was gained from kello variety while the lower was attained form qulle variety. The possible reason for the difference on hatchability could be due to the variation in floral nutrient composition which has been shown above under the section proximate composition analysis. Better nutrient composition of the leaf results to better growth of the larvae leading to health moth and eggs produced from such moth hatches normally. The present result is corroborated with the observations of who found variation in hatchability due to the castor genotypes when used for rearing erisilkworm [65-68].
B. Fecundity (eggs/ female moth): Both first and second cycle of rearing indicated that higher fecundity was recorded from kello variety when compared to qulle variety. The variation in fecundity during first and second cycle with two cassava varieties may be due to the differences in foliar compositions which contribute to the growth and development of silk worms. This is confirmed by the findings of who observed variation in fecundity between different castor genotypes [69,70].

$\mathrm{N}$ application significantly influenced the fecundity of erisilkworm moth. Fewer egg numbers were recorded from the control treatment while the highest fecundity was obtained from the application of $160 \mathrm{~kg} \mathrm{~N} \mathrm{ha}^{-1}$ (Table 3). Fecundity increased as nitrogen level increased. The reduction of fecundity during second cycle might be due to the reduction of nutrients in the leaf as the leaf matured.

\section{Larval parameters}

Significant differences were observed in larval parameters of erisilkworms between the two varieties and different rates of nitrogen in both rearing cycles except for survival rate of the larvae and effective rate of rearing to different rates of nitrogen (Table 4).

A. Larval duration (days): The longest larval duration was recorded from zero application of $\mathrm{N}\left(0 \mathrm{~kg} / \mathrm{ha}^{-1}\right)$ which was not statistically different from $40 \mathrm{~kg} / \mathrm{ha}^{-1}$ nitrogen fertilizer rate. The shortest larval duration was recorded at $160 \mathrm{~kg} \mathrm{~N} \mathrm{ha}^{-1}$. This showed that larval duration decreased with increase in $\mathrm{N}$ fertilizer. Observed negative correlation of nitrogen with larval duration.

Significantly shorter total larval duration was recorded in the larvae fed on Kello variety in rearing cycles, 18.47 and 19.67, respectively. The possible reason for the variation observed in larval duration between the two varieties might be due to their nutritional difference. Better nutrient compositions in the leaves result in to fast growth of the worms and reduce larval duration. Similar results were obtained by who reported that different castor varieties fed to silkworms exhibited differences in larval duration $[66,68]$.

B. Matured larval weight (gm): Larval weight varied very significantly in two cassava varieties. Kello registered higher matured larval weight than Qulle in both rearing cycles (Table 4). The variation in matured larval weight of silkworm fed with two cassava varieties might be due to nutrional difference of leaves which contribute to the growth and development of silkworms. The characters of cocoon primarily depend upon the larval weight. The result of matured larval weight indicated that the feed had significant effect on them. Larval weight can vary depending upon the feed plants which the larvae feed $[57,71]$. These authors observed differences in larval weight when eri worms were fed with leaves of different castor genotypes.

Different rates of $\mathrm{N}$ application resulted in to significant differences in larval weight. The lowest larval weight was registered from the control treatment while the highest larval weight was obtained from the application of $160 \mathrm{~N} \mathrm{~kg} \mathrm{ha}^{-1}$ which is statistically similar with application of $120 \mathrm{~kg} \mathrm{~N} \mathrm{ha}^{-1}$ (Table 4). The highly nutritious and nutrient balanced food is the main factor responsible for healthy growth and development of any insect. Larval weight increased as nitrogen rate increased.

C. Survival rate (\%): The analysis of variance for survival rate 
Citation: Derara Y, Sori W, Nebiyu A, Mulat F. Effect of Nitrogen Rates on Leaf Quality of Two Cassava (Manihot Esculenta Crantz) Varieties as a Feed for Eri-Silkworm (Samia Cynthia Ricini Boisduval) Cocoon Production at Jimma, Southwest Ethiopia. J Plant Biol Soil Health. $2020 ; 6(2)$ : 11.

showed that this trait was not influenced statistically by rates of $\mathrm{N}$ ( $\mathrm{P}$ $<0.05)$ (Table 4).

Varieties showed significant variation on survival rate of erisilkworm. Survival rate of eri-silkworm was higher for Kello when compared to Qulle (Table 4). The study was in line with the work of who found significant differences in survival rate of eri-silkworms when fed on different castor varieties $[65,72]$.

D. Effective rate of rearing (\%): Effective rate of rearing showed significantly different when eri-silkworm fed on two cassava varieties in both rearing cycles (Table 4). Eri-silkworm fed on Kello recorded higher effective rate of rearing than Qulle. Difference in effective rate of rearing was observed among castor genotypes used as feed by earlier workers $[67,68,73-75]$.

The nitrogen rates didn't affect the effective rates of rearing. The reduction of effective rate of rearing during second cycle might be due to the reduction of nutrients in the leaf.

\section{Cocoon parameters}

Cocoon parameters of eri-silkworm (shell weight, cocoon weight and pupal weight) showed significant variations when larvae were fed with two cassava varieties applied with different rates of nitrogen. But, the two varieties during both cycles of rearing and different rates of nitrogen during second cycle of rearing did not show significant differences for silk ratio (Table 5).

A. Single cocoon weight (gm): Significant differences were observed in single cocoon weight of larvae fed with the leaves of two cassava varieties Significant differences were observed in single cocoon weight of larvae fed with the leaves of two cassava varieties grown with different rates of nitrogen in both cycles of rearing (Table 5). Cocoon weight is the most important character for productivity of silk farming [76]. During first and second cycles of rearing, application at $160 \mathrm{~kg} \mathrm{~N} \mathrm{ha}^{-1}$ resulted in to significantly higher cocoon weight (3.66 gm and $3.496 \mathrm{gm}$ ). The lowest was obtained at no application of Nitrogen. The weights of cocoons are significantly influenced by nitrogen content of foliage [32].

Higher cocoon weight was recorded from Kello variety when compared to Qulle. This result is in agreement with the finding of who reported that cocoon weight depends on the type of hosts provided for feeding the larvae [77]. The occurrence of higher values of single cocoon weight on the feed plants of these two cassava varieties in the present study might be due to their higher larval weight gain at the end of the larval feeding period.

B. Shell weight (gm): It is evident that varieties of cassava had significant effect on shell weight of the silkworm during first and second cycle of rearing. Shell weight was found to be significantly higher in Kello as compared to Qulle. This finding is comparable with the reports of who opined that the shell weight varied with the type of hosts provided at the larval stage [65]. Also reported that shell weight varied when eri-silkworms were reared on different varieties of cassava leaves [71].

Different rates of Nitrogen application resulted in to differences in shell weight of eri-silkworms (Table 5). The highest shell weight was observed from application of $160 \mathrm{~kg} \mathrm{~N} \mathrm{ha}^{-1}$ although it was not statistically different from application of $120 \mathrm{~kg} \mathrm{~N} \mathrm{ha}^{-1}$. The lowest was recorded from no application of nitrogen $\left(0 \mathrm{kgN} \mathrm{ha}^{-1}\right)$. The probable reason for the increment of shell weight as the rates of $\mathrm{N}$ increased could be due to the fact that $\mathrm{N}$ is considered as one of the nutrients in the leaf which highly contributes for the growth of larvae and then better shell weight. The reduction of shell weight in the second rearing cycle might be due to the reduction in nutritional status of leaf.

C. Pupal weight (gm): Pupal weight differed significantly between two cassava varieties during both cycles of rearing. During both rearing cycles, the higher pupal weight $(2.96,2.86 \mathrm{gm})$ was registered from Kello variety when compared to Qulle (2.90, 2.76 $\mathrm{gm})$. The result of pupal weight depends on result of cocoon weight and shell weight. This result is in conformity with the findings of who reported that pupal weight depends on the type of hosts provided for feeding the worms $[51,65,72,78-80]$.

The highest $\mathrm{N}$ application, $160 \mathrm{~kg} \mathrm{~N} \mathrm{ha}^{-1}$, resulted into biggest pupal weight and the smallest pupal weight was recorded from no application of nitrogen $\left(0 \mathrm{~kg} \mathrm{~N} \mathrm{ha}^{-1}\right)$ (Table 5). The highest values of pupal weight from the highest application of $\mathrm{N}$ might be due to highest larval weight gain at the end of the larval feeding period [8185].

D. Silk ratio (\%): Silk ratio of eri-silkworm is highly significantly $(p<0.001)$ affected by nitrogen fertilizer rates during both rearing cycles (Table 5). During first rearing cycle, the highest silk ratio was obtained from $120 \mathrm{~kg} \mathrm{~N} \mathrm{ha}^{-1}$ which was not statistically different from the application of $80 \mathrm{~kg} \mathrm{~N} \mathrm{ha}^{-1}$. The lowest silk ratio was recorded from no application of nitrogen $\left(0 \mathrm{~kg} / \mathrm{ha}^{-1}\right)$ which didn't differ statistically from $40 \mathrm{~kg} \mathrm{~N} \mathrm{ha}^{-1}$. During second rearing cycle, the effect of fertilizer did not result in statistically significant $(\mathrm{P}<0.05)$ difference for this parameter (Table 5) [86-89].

There was no variation between varieties for both rearing cycles. This result contradicts with results obtained by who reported that castor varieties were different in silk ratio [65,66,68,90-95].

\section{Conclusion and Recommendation}

The results of analysis of variance revealed significant differences in biochemical composition and rearing performance of silk worms. It was found that varieties and rates of nitrogen showed highly significant influences on mineral and nutrient content of leaf and erisilkworm grainage, larval and cocoon yield parameters. Variety Kello produced higher value for plant leaf nutrient contents (moisture, ash and crude fat), grainage, larval and cocoon parameters (hatchability, fecundity, larval weight, survival rate, effective rate or rearing, cocoon weight, shell weight, pupal weight and silk ratio), while Qulle variety bettered on crude fiber, total carbohydrate and larval duration.

$\mathrm{N}$ application at $160 \mathrm{~kg} \mathrm{~N} \mathrm{ha}^{-1}$ resulted to maximum value for proximate composition of the leaf (moisture), and for eri-silkworm parameters (hatchability, fecundity, larval weight, single cocoon weight, shell weight, pupal weight and shell ratio). The highest values for crude fiber and total carbohydrate were recorded from no application of urea. Combined application of $160 \mathrm{~kg} \mathrm{~N} \mathrm{ha}^{-1}$ and use of Kello cassava variety showed higher mean number for nitrogen and crude protein. The least record in all parameters was from the control treatment except for crude fiber and carbohydrate. 
Citation: Derara Y, Sori W, Nebiyu A, Mulat F. Effect of Nitrogen Rates on Leaf Quality of Two Cassava (Manihot Esculenta Crantz) Varieties as a Feed for Eri-Silkworm (Samia Cynthia Ricini Boisduval) Cocoon Production at Jimma, Southwest Ethiopia. J Plant Biol Soil Health. $2020 ; 6(2)$ : 11.

In conclusion, cassava can grow well in the study area and farmers can benefit more by using the application of $160 \mathrm{~kg} \mathrm{~N} \mathrm{ha}^{-1}$ which resulted in maximum leaf yield, leaf quality and cocoon productivity and the variety kello which is more productive in terms of leaf quality and cocoon productivity.

However, more research should also be carried out to support the current findings in the following areas:

1. Amount and frequency of leaf defoliation should be studied.

2. Appropriate integration of eri silkworm rearing with cassava tuber production.

3. Other nutrients and minerals in the leaf should further be explored in that they have relationship with rearing performance of eri-silkworm.

4. Cost benefit analysis should to be done.

5. Similar experiments are suggested to be carried out at different seasons and different locations because repetition of the experiment for more seasons and locations would help us to draw sound conclusions and recommendation.

\section{References}

1. AOAC (2000) Methods of analysis. Association of Official Agricultura Chemists ( $\left.7^{\text {th }} \mathrm{Edn}\right)$. AOAC International, Gaithersburg, MD.

2. Adepoju OT, Nwangwu JO (2010) Nutrient composition and contribution of noodles (abacha) and local salad from cassava (Manihot spp) to nutrien intake of Nigerian consumers. African J Food Sci 4: 422-426.

3. Ahmed I (2015) Studies on the Effect of Wet Castor Leaf Feeding and Feeding Frequencies on Economic Traits of Eri-silkworm, Samia cynthia ricin (Saturnidae: Lepidoptera). Sci Technol Arts Res j 4: 63-67.

4. Ahmed I, Kedir S, Abiy T, Metasebia T (2015) Evaluations of Different Mountage Types and Sizes on Eri and Mulberry Feeding Silkworms Cocoon Yield and Quality of Silk, at Melkassa Agricultural Research Center, East Shoa, Ethiopia Sci Technol Arts Res J 4: 48-52.

5. Basaiah JM (1988) Consumption and utilization of castor and tapioca by the eri silkworm. M.Sc. (Seri.) Thesis, University of Agricultural Sciences, UAS, Bangalore 119.

6. Berhanu A (2004) The Food Security Role of Agriculture in Ethiopia Electronic Journal of Agricultural and Development Economics 1: 138-153.

7. Bezabih Emana and Hadera G/medhin (2007) "Constraints and Opportunities of Horticulture Production and Marketing in Eastern Ethiopia". DCG Report No.46: 2 .

8. Bhat GG, UmeshT, Naik R (1991) Tapioca is an ideal root upon which to rear the eri-silkworm. Indian Silk 19-20.

9. BPEDORS (2000) Physical and socio economic profile of 180 district of Oromia regions. Physical Planning Development Finfinne 248-251.

10. Chandrappa D, Govindan R, Sannappa B (2005) Quality and biochemical constituents of leaves as influenced by some castor genotypes. International Journal of Agriculture Science. 177-79.

11. Chandrashekhar S, Sannappa B, Manjunath KG, Govindan R (2013) Nutritive Value of Leaves in Different Genotypes of Castor (Ricinus communis
L.) Indian Journal of Plant Sciences 2: 22-27.

12. Chandrashekhar S, Sannappa B, ManjunathKG, GovindanR (2012) Efficacy of castor genotypes on bio-assay, cocoon and grainage traits of the domesticated vanya silkworm Samia Cynthia ricini Boisduval. Journal of Pharmacy Research 5: 1346-1349.

13. Chowdhury SN (1982) Eri silk Industry. Directorate of Sericulture and Weaving, Government of Assam 171-175.

14. Cock JH (1984) Cassava. In: P.R. Goldsworthy and N.M. Fischer (Editors). The physiology of tropical field crops. John Wiley and Sons Ltd. 529-549.

15. Dandin SB, JayaswalJ, Giridhar K (2003) Handbook of Sericulture Technologies, CSB, Bangalore, 259.

16. Dash R, Ghosh SK, Kaplan DL, Kundu SC (2007) Purification and biochemical characterization of a70kDa serin from tropical tasar silkworm, antheraea mylitta. comp Biochem Physiol B Biochem Mol Biol 147: 129-134.

17. Dayashankar KN (1982) Performance of erisilkworm, Samia Cynthia ricini Boisduval on different host plants and economics of rearing on castor under Dharwad conditions. M.Sc. Thesis, University of Agricultural Sciences, Bangalore 60-86.

18. Debaraj Y, SinghBK, Das PK, Suryanarayan N (2003) An evergreen host plant of eri silkworm. Indian silk 5: 5-6.

19. Degnet Abebaw, Belay Kasa (2001) Factors Influencing Adoption of High Yielding Maize Varieties in South West Ethiopia: An Application of Logit Analysis' Quarterly Journal of International Agriculture 40: 149-167.

20. Devaiah MC, Dayashankar KN (1982) Effect of different host plants on the economic traits of eri silkworm, Samia cynthia ricini (Lepidoptera, Saturniidae). National seminar on silk research and development, CSB, March 10- 13, Bangalore 152.

21. DOA (Department of agriculture) (2009). GAP No.3. Department of agriculture. Bangkok.

22. Dookia BR (1980) Varied silk ratio in cocoons of eri silkworm (Philosamia ricini Hutt.) reared on different castor varieties in Rajasthan. Indian J Seric 19: $38-40$.

23. Eaton FM (1942) Toxicity on accumulation of chloride and sulphate salts in plant. Journal of Agricultural Reserch 64: 359-399.

24. EL-Shaarawy MF, GommaAA, EL-GarthyAT, 1975a. Chemical determination and utilization of dietary constituents of two castor bean varieties by larvae of the eri silkworm, Attacus ricini Boisduval. Z. Journal of Angewandte Environments 78: 171-176.

25. FAOSTAT (2009) The Food and Agricultural Organization Data Base Result.

26. FAOSTAT (2012) Food and agriculture organization of the United Nations. FAOSTAT, Rome,

27. Gangopadhyay (2008) Silk Industry in India- A Review, Indian Science \& Technology; NISTDS CSIR New Delhi.

28. Gangwar SK (2010) Impact of varietal feeding of eight Mulberry varieties on Bombyx mori L Agric. Biol J N Am 1: 350-354.

29. Gaviria DA, SerranoHJ, AlegriaAH (2006) DNA fingerprinting using AFLP markers to search for makers associated with yield attributes in the silkworm Bombyx mori. J Insect Sci 6:15 
Citation: Derara Y, Sori W, Nebiyu A, Mulat F. Effect of Nitrogen Rates on Leaf Quality of Two Cassava (Manihot Esculenta Crantz) Varieties as a Feed for Eri-Silkworm (Samia Cynthia Ricini Boisduval) Cocoon Production at Jimma, Southwest Ethiopia. J Plant Biol Soil Health. $2020 ; 6(2)$ : 11.

\section{ISSN: 2331-8996}

30. Goel RK, Krishan RaolV (2004) Oka Tasar Culture: Aboriginal of Himalayas. Darya Ganj New Delhi, India.

31. GogoiB, Goswami BC (1998) Studies on certain aspects of wild eri silkworm (Philosamia cynthia Drury) with special reference to its rearing performance. Sericologia 38: 463-472.

32. Govindan R, Sannappa B, Bharathi VP, Singh MP, Hegde DM (2002) Elemental composition of leaves of different varieties of castor, Ricinus communis L. Environmental Ecology 20: 955-959.

33. Govindan R, Sannappa B, Bharathi VP, Ramakrishna N (2002). Influence of castor genotypes on economic traits of eri silkworm. Insect Environ 8: 72-73.

34. Govindan R, SannappaB, BharathiVP, SinghMP, HegdeDM, 2003a. Nutritive value of leaves of different varieties of rainfed castor (Ricinus communis L.). Crop Research 25: 444-448.

35. Govindan R, Sannappa B, BharathiVP, SinghMP, HegdeDM, 2003b. Quality parameters of leaves of some castor varieties with varied cultivation practices in different locations of Karnataka. Indian Journal of Environtal Ecoplannning. 7: 307-310.

36. Govindan R, Devaiah MC, RangaswamyHR, 1978. Effect of different food plants on the growth of Philosamia ricini Hutt. All India Symp. On Seric. Sci., Oct 23-26. (Abstr. 49).

37. Gulrajani, M.L. (1988) Degumming of silk; in Silk dyeing printing and finishing, M.L. Gulrajani (ed), Department of Textile Technology Indian Institute of Techno- logy, New Delhi. pp. 63-95.

38. Hazarika U, BarahA, PhukonJD, BenchaminKV, 2003. Studies on the effect of different food plants and seasons on the larval development and cocoon characters of silkworm Samia cynthia ricini Biosduval. Indian Acad. Sericulture.7 (1): 77-85

39. Hehl G, MengelK, 1972. The effects of potassium and nitrogen on carbohydrate content of several forage crops. Agric. Res. 27(11): 117-129.

40. Hofman G, CleemputOV (2004) Soil and Plant Nitrogen 1st version. IFA Paris, France. 49.

41. Huq SB, Haque MA, Khan AB (1991) "Rearing Performances of Eri-silkworm, Philosamia ricini Hutt. (Lepidoptera: Saturniidae) on Five Different Host Plants", Bangladesh Journal of Agricultural Sciences 18: 169-171.

42. Jayaprakash P, Sasikala A, Suryanarayana N (2005) Ericulture- A tool for rural women development in Andhra Pradesh, India. Conference Papers (3.18) In: The 20th Congress of International Sericultural Commission, Bangalore. 106-109.

43. Jayaraj S, Reddy R, Madesu C,Qadri SM, Krishna RJ Sakthive IN (2006) Ericulture in Tamil Nadu, Pondicherry and Kerala states in India: A study on feasibility, technology development, refinement and transfer. Half Yearly Progress Report for the Period Ending June 2006, Central Silk Board, Bangalore, India 27-43

44. Joshi KL (1992) Evaluation of diets for larvae of the eri-silkworm Samia Cynthia ricini (Boisd) (Lepidoptera: Saturniidae). Indian Journal of Sericulture 3: $49-51$

45. Joshi KL, Misra SD (1982) Silk Percentage and effective rate of rearing of er silkmoth, Philosamia ricini Hutt. (Lepidoptera: Saturniidae). Entomol 7: 107110.
46. Kavane RP (2014) A potential new host of philosamia ricini eri silkworm under western maharashtra condition. International Journal of Advanced Research 2: $433-438$

47. Kedir S (2011) Studies on the Performance of Eri-Silkworm (Samia cynthia ricini Boisduval) (Lepidoptera: Saturniidae) Fed on Different Genotypes of Castor (Ricinus communis L.) An MSc Thesis presented to the School of Graduate Studies of Addis Ababa University. 22-42.

48. Kedir S (2016) Evaluation of foliar proximate compositions of castor genotypes and their relationship with productivity of eri silkworms (Samia cynthia ricini B.) International Journal of Innovative and Applied Research 4: 16-27.

49. Kedir S, Emana G, Waktole S (2014) Rearing Performance of Eri-Silkworm (Samia cynthia ricini Boisduval) (Lepidoptera: Saturniidae) Fed with Different Castor (Ricinus communis L.) Genotypes. Journal of Entomology 11: 25-33.

50. Komatsu K (1975) Studies on dissolution behaviors and structura characteristic of silk Sericin. Bull. Sericult Exp Sta 26: 135-256.

51. Krishnaswami S, 1978. New Technology of Silkworm Rearing. Bulletin No.3, Central Sericultural Research and Training Institute, Mysore, India.

52. Krishnaswamy S, MadhavaRN, SuryanarayanaSK, 1972. Sericulture Manual-3, Silk Reeling, F.A.O, Rome. pp: 112

53. Kumar R, Gangwar SK (2010) Impact of varietal feeding on Samia ricin Donovan in spring and autumn season of Uttar Pradesh. ARPN J Agric Biol Sci, 5: 46-51.

54. Kumar R, VadamalaiE (2010) Rearing Performance of Eri Silkworm Philosamia riciniin Monsoon Season of Uttar Pradesh. Asian J Exp Biol Sci. 1: 303-310.

55. Lakshmi R( 2007) Potential for participation of women in sericulture sector The National Conference on women Sericulture held at Mysore on 16th and 17th March.

56. Legese Dady (2004) Agricultural Research and Technology Development in Ethiopia. Proceedings of the workshop held to discuss the socio-economic research results of 1998-2002. August 6-8, 2002, Addis Ababa, Ethiopia. EARO.

57. Mallette MF, AlthousPM, ClagettaCO (1960) Biochemistry of Plants and Products. New Delhi, India. Wiley Eastern Pvt. Ltd.

58. Malik FA, ReddyYS (2007) Role of mulberry nutrition on manifestation of post cocoon characters of selected races of the silkworm Bombyx mori L.Sericologia 47: 63-76.

59. Maynard AL, LoosliL (1962) Animal Nutrition,5th edn.M.C. Graw Hill Book Co., Inc., New York, 533.

60. Mengel K, Kirkby EA (1979) Principles of plant nutrition International Potash Institute. Berne. Switzer1 and. 309-346.

61. Metaferia HY, Amanuel T, Kedir S (2007) Scaling up of silk production technologies for employment and income generation in Ethiopia. In: Success with Value Chain: proceedings of scaling up and scaling out of agricultural technologies in Ethiopia, an international conference, 9-11 May 2006 (Tsedeke Abate ed). Ethiopian Institute of Agricultural Research, Addis Ababa

62. Miller WE (2005) Extrinsic effects on fecundity-maternal weight relations in capital-breeding Lepidoptera J Lepidopterans Soc 59: 143-160. 
Citation: Derara Y, Sori W, Nebiyu A, Mulat F. Effect of Nitrogen Rates on Leaf Quality of Two Cassava (Manihot Esculenta Crantz) Varieties as a Feed for Eri-Silkworm (Samia Cynthia Ricini Boisduval) Cocoon Production at Jimma, Southwest Ethiopia. J Plant Biol Soil Health. $2020 ; 6(2)$ : 11.

\section{ISSN: 2331-8996}

63. Narayanaprakash R, PeriasamyK, Radhakrishnan S (1985) Effect of dietary water content on food utilization and silk production in Bombyx mori L. (Lepidoptera: Bombycidae). Indian J Seric 24: 12-17.

64. Nataraju B, KSathyaprasad, D Manjunath, CA Kumar (2005) Silkworm Crop Protection. Central Silk Board, Bangalore 412

65. Olsen RA, KurtzLT (1982) Crop nitrogen requirements, utilization and fertilization..567-604. in: F.J, Stevenson (ed.). Agronomy: Nitrogen in agricultural soils. Madison, Wisconsin, USA.

66. Pandey RK (2003) Ericulture in Uttar Pradesh. Indian Silk 41: 21-24

67. Patil GM, KulkarniKA, PatilRK, BadigerKS (2000) Performance of er silkworm, Samia Cynthia ricini Boisd. On different castor genotypes. Internat. J. Wild Sikmoth \& Silk 5: 193-195.

68. Rahmathulla VK, TilakR, RajanRK (2006) Influence of Moisture Content of Mulberry Leaf on Growth and Silk Production in Bombyx mori L. Caspian J Env Sci 4: 25-30.

69. Raina SK (2004). On developing incentives for community participation in forest conservation through the use of commercial insects in Kenya. ICIPE science press, Nairobi 200-213.

70. Rajadurai S, TomyP, ShekharMA (2010) Seasonal rearing performance of eri silkworm (Philosamia ricini Boisduval) on castor and tapioca under South Karnataka conditions I J Seric 49: 134-137.

71. Rajesh K, Gangwar SK (2010) Impact of varietal feeding on Samia ricini Donovan in spring and autumn season of Uttar Pradesh. ARPN Journal of Agricultural and Biological Science 5: 46-48

72. Ramakrishna N, Sannappa B, GovindanR (2003) Influence of castor varieties on rearing and grainage performance of different breeds of eri silkworm, Samia cynthia ricini. J Ecobiol 15: 279-285.

73. Ranjhan SK, Krishna G (1981) Laboratory Manual for Nutrition Research, Vikas pub. House Pvt. Ltd., New Delhi 45-67.

74. Rao JV (2003) Large scale development of ericulture in India. Indian silk 42 : $27-29$

75. Reddy DN, KotikalYK, VijayendraM (1989) Development and silk yield of eri silkworm Samia cyanthia ricini Boisdual, (Lepidopters: saturnidae) as influenced by the food plant. Mysore J Agric Sci 23: 506- 508

76. Sahlemedhin S, Taye B (2000) Procedures for soil and plant analysis. Technical paper, Ethiopian Agricultural Research Organization, Addis Ababa 60-83.

77. Sakthivel N (2012) Studies on utilization of tapioca (Manihot esculenta Crantz) for ericulture in Tamil Nadu. Ph.D. (Sericulture) thesis, Periyar University, Salem - 636 011, Tamil Nadu 175-178.

78. Sannappa B, Jayaramaiah J (1999) Mineral Constituents of Selected Genotypes of Castor, Ricinus communis L. Mysore J agric Sci 33: 157-161.
79. Sannappa B, Jayaramaiah M (2002) Foliar constituents of selected genotypes of castor Ricinus communis L. Mysore Journal Agricultural Science 36: 315321.

80. Sarkar DC (1980) Eri culture in India. Central Silk Board. Bangalore, India $1-49$

81. Sarkar DC (1988) Ericulture in India. Central Silk Board, Grafo Printers 1- 49

82. Sarmah MC, ChutiaM, NeogK, DasR, Rajkhowa G ( 2011) Evaluation of promising castor genotype in terms of agronomical and yield attributing traits, biochemical properties and rearing performance of eri silkworm, Samia ricin (Donovan). Industrial Crops and Products 34: 1439-1446.

83. Sarmah MC, Datta RN, Das PK, Benchamin KV (2002) Evaluation of certain castor genotypes for improving ericulture. Indian J Sericulture 41: 62-63.

84. Sarmah MC, Neog K, Das A, Phukan JCD (2013) Impact of soil fertility and leaf nutrients status on cocoon production of Muga silkworm, Antheraea assamensis (Helfer) in potential muga growing areas of Assam, India, Int $\mathrm{J}$ Curr Microbio App Sci 2: 25-38.

85. SAS Institute, Inc, 2008. JMP .Version 3.1. Cary, North Carolina.

86. Scott GJ, Rosegrant M, Ringler C, 2000. Roots and tubers for the 21st century: Trends, projections and policy options. Food, Agriculture and the Environment Discussion Paper 31. Washington, D.C: International food policy research institute (IFPRI) and International.

87. Seidavi A, Bizhannia AR, Sourati R. MavvajpourM. (2005). The nutritional effects of different mulberry varieties on biological characters in silkworm. Asia Pac J Clin Nutr 14: 122

88. Selema MD, FaragoME (1996) Trace element concentrations in the fruit peels and trunks of Musa paradisiacal Phytochemistry 42: 1523-1525.

89. Shao Z, VollrathF (2002) Surprising strength of silkworm silk. Nature 418: 741-742.

90. Singh BK, Sahu J, Krishna Rao JV, Das PK (2004) Sustainable development of traditional States through improved rearing practices. In: Proceedings of National Workshop on Potential and Strategies for Sustainable development of Vanya Silks in the Himalayan States, Dehradun 236-239.

91. Singh BK, Debaraj Y, Sarmah MC, Das PK, Suryanarayana N (2003) Ecoraces of eri silkworm. Indian Silk 42: 7-10.

92. Singh KC, BenchaminKV (2002) Biology and ecology of the eri silk moth, Samia ricini Donovan, Saturniidae: A review. Bulletin of Indian Academy of Sericulture. 6: 20-33.

93. Usha Rani (2007) Employment Generation to Women in Drought Prone Areas: A Study with Reference to the Development of Sericulture in Anantapur District of Andhra Pradesh; Journal. of Soc. Science 14: 249-255.

94. Virk JS, Rabinder K, ParwinderK (2009) Performance of eri silkworm, Samia cynthia ricini Doisduval in different seasons of Punjab. Indian J Seric 48: 7880 .

95. World Bank (2006) Africa Development indicators Washington DC 4. 